\title{
TRANSFER TEKNOLOGI SAMBUNG MENGGUNAKAN ANAKAN (Root-sucker) SEBAGAI BATANG BAWAH UNTUK PROPAGASI TANAMAN KESEMEK DI BATU BAGIRIEK ALAHAN PANJANG
}

\author{
P.K. Dewi Hayati ${ }^{1)}$, Sutoyo $^{2)}$, Netti Herawati ${ }^{3)}$, Irfan Suliansyah $^{4)}$, Nini Marta ${ }^{5)}$ \\ dan Kuswandi ${ }^{6}$ \\ ${ }^{1,2,3,4)}$ Fakultas Pertanian Universitas Andalas \\ ${ }^{5,6)}$ Balai Penelitian Tanaman Buah (Balitbu) Tropika Solok \\ Email : pkdewihayati@agr.unand.ac.id
}

Received : 19 Juni 2018. Accepted 13 Juli 2018. Published online 5 September 2018

\begin{abstract}
ABSTRAK
Persimmon, kesemek, buah kaki atau manggih hutan dalam bahasa minang adalah berbagai sebutan untuk buah yang dihasilkan oleh tanaman pohon Diospyros kaki Thunb. Buah kesemek mengandung berbagai nutrisi penting, anti toksik dan bahkan anti kanker. Kesemek merupakan tanaman sub tropika sehingga di Indonesia kesemek hanya beradaptasi pada ketinggian \pm 1400 mdpl, seperti Alahan Panjang. Petani biasanya menggunakan anakan untuk perbanyakan, namun akibatnya tanaman membutuhkan waktu yang lama untuk berbuah, lebih dari 8 tahun. Kegiatan ini bertujuan untuk mentransfer teknologi sambung pucuk menggunakan anakan (root-sucker) sebagai batang bawah (root-stock) sebagai upaya untuk mendapatkan perbanyakan kesemek secara cepat dan tanaman cepat berbuah. Mitra kegiatan ini adalah kelompok tani Harapan Baru yang berada di Batu Bagiriek Alahan Panjang Kabupaten Solok, Sumatera Barat dari bulan Oktober hingga Desember 2016. Metode kegiatan meliputi penyuluhan, demonstrasi dan pelatihan grafting. Hasil kegiatan adalah petani meningkat pengetahuannya tentang manfaat buah kesemek, teknik budidaya dan pasca panen serta mampu melakukan grafting atau penyambungan pada kesemek menggunakan root-sucker (anakan) sebagai batang bawah. Berdasarkan hasil uji statistika menggunakan analisis Likert, kegiatan yang dilakukan memiliki nilai indeks 92, menunjukkan bahwa kegiatan yang dilakukan bermanfaat atau berhasil mentransfer pengetahuan dan juga keterampilan kepada petani.
\end{abstract}

Kata kunci: tanaman sub-tropika, perbanyakan, propagasi vegetatif, sambung pucuk

\section{Transfer of Grafting Technology using Root-Sucker as Root-Stock for Persimmon Propagation in Batu Bagiriek Alahan Panjang}

\begin{abstract}
Persimmon, kesemek, buah kaki, or manggih hutan are vern names of Diospyros kaki Thunb. The fruit has a variety of nutritional and nutraceutical values as antioxidant and anticancer. Persimmon is a sub-tropical plant thus in Indonesia persimmon is only adapt at an altitude of $\pm 1400 \mathrm{~m}$ above sea level as in Alahan Panjang. Farmers usually use root-sucker for propagation; however it takes more than 8 years to produce. The aim of activity was to transfer grafting technology using root-sucker as root-stock in order to obtain persimmon propagation that produces early. The activities have been conducted on kelompok tani Harapan Baru Batu Bagiriek Alahan Panjang Kabupaten Solok, Sumatra Barat province from September to December 2016. Methods of activities include community learning, demonstration of a various grafting techniques and training. Results of the activities are the farmers gain knowledge regarding nutritional and nutraceutical values of fruit, cultivation techniques and post harvest of fruit. The farmers are also capable in grafting to propagate persimmon. Based on statistical test using Likert analysis, the community service activities have index 92, indicating that activities are useful or successful to transfer knowledge and skill to the farmers.
\end{abstract}

Key words: sub-tropic crop, propagation, vegetative propagation, top grafting 


\section{PENDAHULUAN}

Buah kesemek, buah kaki, persimmon atau yang dikenal sebagai "manggih hutan" dalam bahasa minang adalah berbagai sebutan untuk tanaman introduksi yang dihasilkan oleh tanaman pohon Diospyros kaki Thunb. Buah kesemek mengandung berbagai nutrisi seperti vitamin dan mineral, antioksidan seperti $\beta$-carotene, $\beta$ cryptoxanthin, lutein, zeaxanthin dan lycopene, serta pro vitamin A (Chen et al., 2005; Jung et al., 2008). Nazir et al. (2013) melaporkan bahwa buah kesemek mengandung aktivitas antiproliferative sebagai anti kanker. Buah biasanya dikonsumsi segar agar kandungan vitamin dan antioksidan tetap terjaga. Namun kesemek juga dapat diolah menjadi berbagai jenis makanan dan minuman antara lain manisan, jus, campuran pembuatan kue, sale dan selai.

Satu-satunya daerah penghasil buah kesemek di Sumatera Barat adalah Alahan Panjang, kabupaten Solok. Hal ini disebabkan karena kesemek merupakan tanaman sub tropika sehingga di daerah tropika, kesemek hanya beradaptasi pada ketinggian 10001500 dpl. Dengan demikian Alahan Panjang menjadi daerah yang cocok untuk pengembangan tanaman ini.

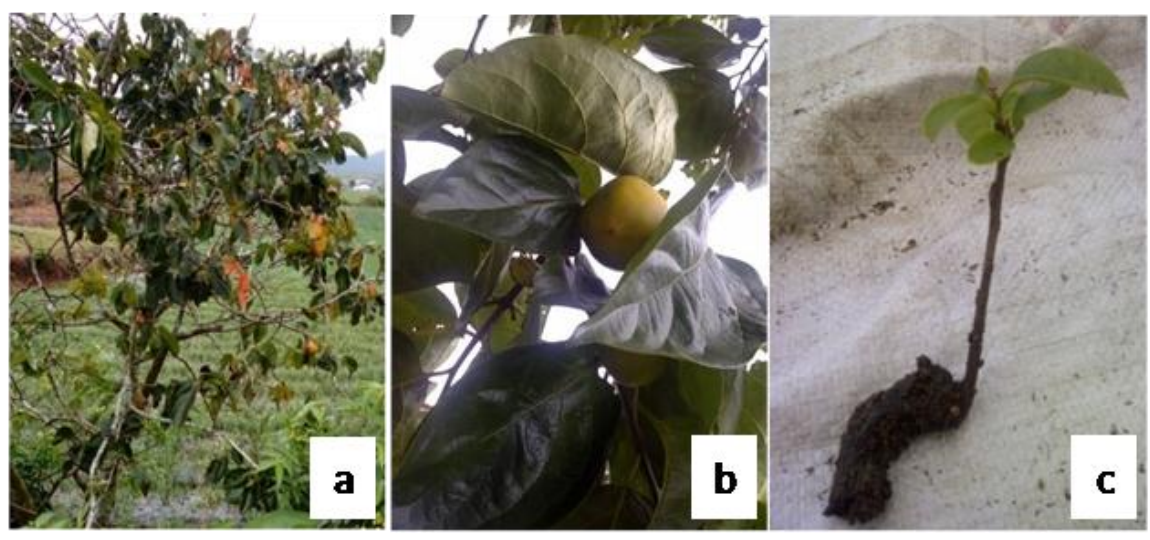

Gambar 1. Tanaman Kesemek di Alahan Panjang; (a) Pohon Kesemek, (b) Bentuk Daun dan Buah (c) Anakan Root-Sucker

Saat ini, tanaman kesemek (Gambar 1) sudah semakin sedikit dijumpai karena keengganan masyarakat melakukan kultur teknis pemeliharaan pada tanaman kesemek yang sudah ada, apalagi menanam tanaman kesemek yang baru (replanting). Ada beberapa faktor penyebab keengganan tersebut antara lain karena masyarakat tidak tahu manfaat atau kandungan nutrisi dan kesehatan yang dimiliki buah ini sehingga buah belum dihargai tinggi sebagaimana di luar negeri disamping juga belum ada pasar yang jelas. Selain itu kesemek juga memiliki masa juvenil yang panjang, 8-12 tahun untuk mulai berbuah karena tanaman kesemek di Alahan Panjang berasal dari anakan. Walaupun bisa dilakukan pencangkokan, namun teknik ini jarang sekali digunakan untuk perbanyakan. Sementara itu penyetekan tidak dilakukan karena sulitnya tanaman berakar. Oleh karena itu transfer teknologi tepat guna bagi perbanyakan kesemek untuk menghasilkan tanaman kesemek yang cepat berbuah menjadi penting.

Grafting merupakan teknik penyambungan antara batang bawah (root stocks) dengan batang atas (scion). Setek banyak digunakan sebagai batang bawah untuk perbanyakan masal (Tetsumura et al, 2000). Namun karena sulitnya perakaran setek (Dewi-Hayati et al, 2014), maka anakan (root-sucker) menjadi alternatif untuk 
propagasi kesemek dalam rangka mendapatkan tanaman kesemek yang cepat berbuah. Satu tanaman kesemek dapat menghasilkan hingga lebih dari Kerjasama dengan Balai Penelitian Tanaman Buah (Balitbu) Tropika Solok mengenai status penelitian dan pengembangan tanaman kesemek di Alahan Panjang, menunjukkan bahwa tingkat keberhasilan grafting menggunakan anakan $\pm 60 \%$, mengindikasikan tingkat kompatibilitas dan keberhasilan penyambungan yang cukup tinggi.

Khalayak sasaran adalah Kelompok Tani Harapan Baru yang berada di sekitar PATPKP (Pusat Alih Teknologi dan Pengembangan Kawasan Pertanian) Universitas Andalas, Batu Bagiriek Alahan Panjang. Mitra merupakan petani hortikultura sayuran namun masih menanam tanaman kesemek di pinggir lahan atau di halaman. Pohon kesemek sudah sangat jarang dijumpai karena belum ada usaha petani untuk mengembangkan dan memperbanyak tanaman kesemek. Tujuan kegiatan ini adalah memberikan transfer teknologi grafting kepada petani. Luaran dari kegiatan ini adalah petani mengetahui tentang manfaat buah kesemek, teknik budidaya dan pasca panen serta mampu melakukan sambung pucuk (top grafting) menggunakan anakan (rootsucker) sebagai batang bawah untuk mendapatkan tanaman kesemek yang berbuah lebih cepat.

\section{METODE}

Kegiatan ini dilakukan pada kelompok tani Harapan Baru, Batu Bagiriek Alahan Panjang dari bulan September hingga Desember 2016. Metode yang diterapkan pada kegiatan ini meliputi penyuluhan, demonstrasi dan pelatihan (Efrizal dkk, 2018; Syaiful, 2018) Untuk pelatihan grafting yang dilakukan pada hari yang berbeda sesuai dengan kesepakatan pada saat sosialisasi. Materi penyuluhan meliputi sosialisasi manfaat buah kesemek, teknik budidaya dan pasca panen.

Demonstrasi berbagai macam teknik grafting dan perbanyakan vegetatif lainnya dilakukan langsung oleh nara sumber sebelum pelatihan. Selanjutnya masing-masing petani mencobakan teknik grafting maupun teknik perbanyakan vegetatif lainnya dengan menggunakan pisau dan gunting stek yang dibagikan. Penyambungan dilakukan oleh setiap petani yang berkelompok 2-4 orang dan didampingi oleh narasumber. Petani melakukan penyambungan hingga teknik/cara dan hasil yang diperoleh sudah sesuai dengan ketentuan. Di akhir kegiatan bibit hasil grafting dari hasil pembibitan yang telah dilakukan sejak tahun 2015 dan juga bibit hasil sambung yang dilakukan oleh petani sendiri dibagikan kepada masing-masing petani.

Analisis terhadap seberapa besar kegiatan yang dilakukan dibutuhkan dan bermanfaat bagi petani dilakukan dengan cara memberikan kuesioner pada akhir kegiatan. Jumlah petani yang menjadi responden adalah 30 orang. Hasil kuesioner ditabulasikan dan dianalisis secara statistika menggunakan analisis Likert (Suryabrata, 2012).

\section{HASIL DAN PEMBAHASAN}

Pelaksanaan kegiatan ini meliputi beberapa kegiatan yang dilakukan berurutan. Tahapan awal adalah sosialisasi kegiatan kepada masyarakat melalui ketua kelompok mengenai rencana pelaksanaan kegiatan transfer teknologi sambung ini. Sosialisasi 
kegiatan mencakup jadwal pelaksanaan kegiatan, tempat pelaksanaan dan material serta bahan-bahan apa yang mesti dipersiapkan oleh kelompok tani. Selanjutnya dilakukan penyuluhan yang berisikan pengenalan manfaat tanaman kesemek, budidaya dan pasca panen buah kesemek (Gambar 2).
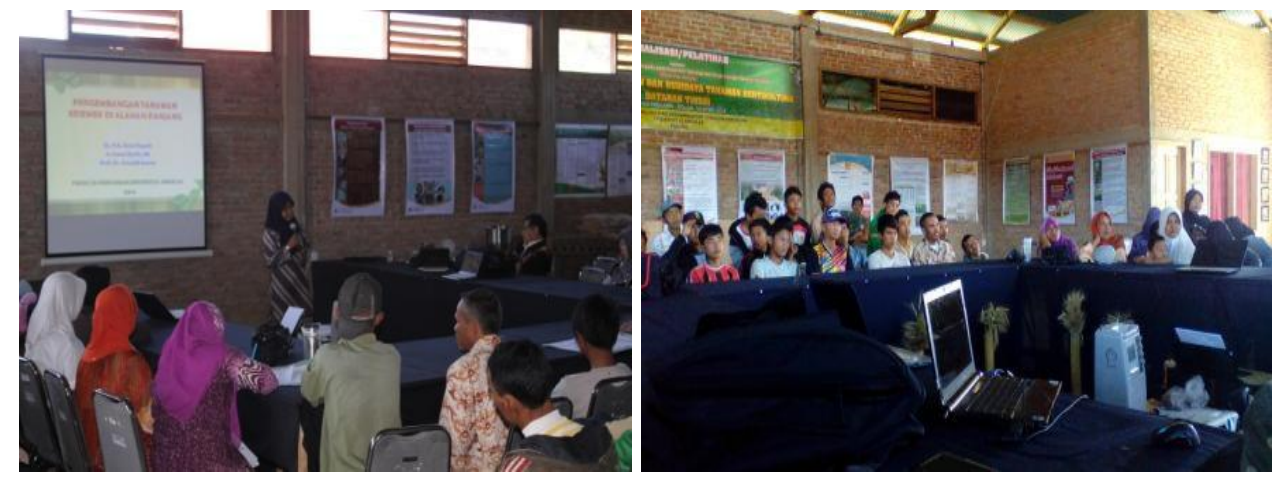

Gambar 2. Penyuluhan Mengenai Manfaat, Budidaya dan Pasca Panen Kesemek

Berdasarkan hasil tanya jawab dan diskusi saat penyuluhan diketahui bahwa ternyata petani belum tahu manfaat buah kesemek selain dari sebagai buah meja yang di konsumsi segar, sedangkan buah sebenarnya bisa di buat selai, sale/ salai, dikeringkan dan di buat menjadi makanan olahan lainnya. Petani juga tidak banyak mengetahui pasca panen buah kesemek selain daripada direndam dengan air kapur atau lumpur untuk menghilangkan rasa kelat pada buah.

Tipe kemasakan buah kesemek di Alahan Panjang adalah tipe astringent atau memiliki rasa kelat sebelum matang. Oleh karena itu buah harus dipanen saat matang yang ditandai dengan perubahan warna dari hijau menjadi kuning oren yang merata pada seluruh permukaan buah, walaupun daging buah masih keras. Seludang dan tangkai sebaiknya dibiarkan menempel untuk mencegah kebusukan buah. Untuk menghilangkan rasa kelat, maka buah dapat direndam dengan air kapur atau air garam, membedaki dengan kapur, dipanaskan dengan air mendidih 2-3 menit diikuti dengan perendaman dalam air dingin atau pembekuan 2-4 jam kemudian dibiarkan dalam ruang terbuka.

Perbanyakan tanaman kesemek dapat dilakukan secara generatif maupun secara vegetatif. Perbanyakan secara generatif menggunakan benih tidak dilakukan karena ukuran biji yang kecil, jumlah yang sedikit ( $<10$ biji per buah) dan sulit berkecambah. Selain itu kualitas buah tidak sama dengan tanaman induknya disamping dibutuhkan waktu yang lama untuk berproduksi. Perbanyakan secara vegetatif atau menggunakan bagian tanaman dapat dilakukan dengan setek, anakan (root-sucker), sambung (grafting) dan penempelan (budding).

Anakan merupakan tanaman baru yang tumbuh di sekitar tanaman induk/utama yang berasal dari tunas yang keluar dari bagian bawah tanaman induknya sehingga sering disebut sebagai tunas akar (root-sucker). Oleh karena itu sistem perakaran pada tanaman yang diperbanyak dari anakan lebih kuat karena memiliki perakaran dalam dibandingkan dengan perakaran dari setek. Namun perbanyakan menggunakan anakan ini juga membuat tanaman berbuah dalam waktu lama sebagaimana perbanyakan menggunakan biji. Sebaliknya perbanyakan menggunakan setek bagian tanaman menghasilkan tanaman yang cepat berbuah karena berasal dari bagian tanaman yang 
sudah berbuah, namun demikian setek cabang yang dilakukan pada kesemek memiliki tingkat keberhasilan yang rendah (Dewi-Hayati, 2014).

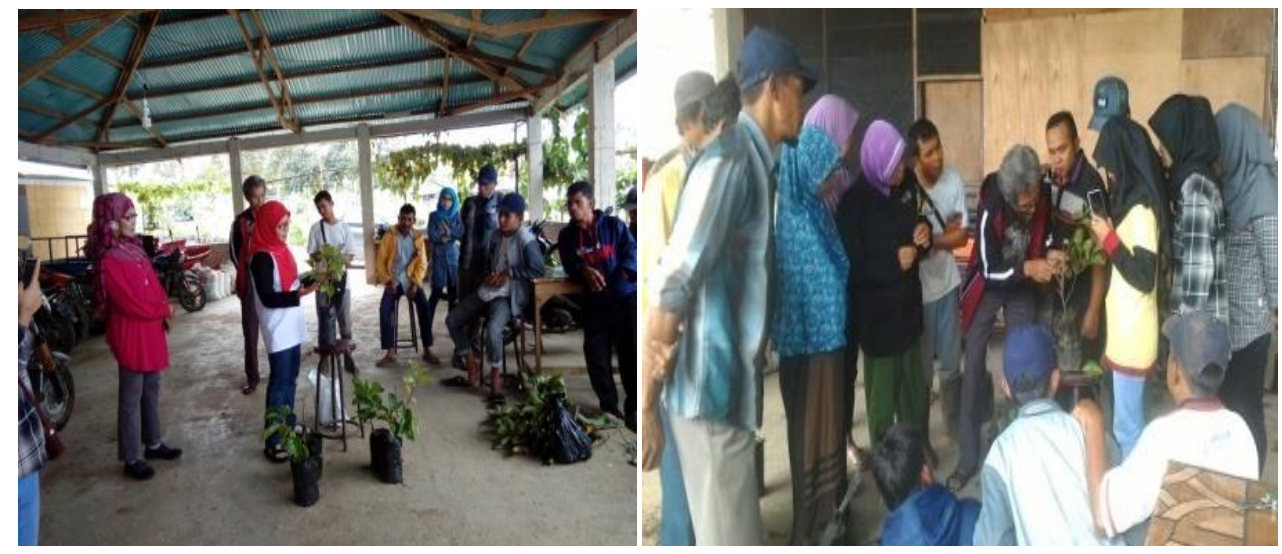

Gambar 3. Demonstrasi Beberapa Teknik Grafting-Yang Dapat Dilakukan Kepada Petani

Demonstrasi penyambungan kesemek dilakukan sebelum kegiatan pelatihan (Gambar 3). Pada saat demonstrasi, diterangkan dasar pemilihan anakan (root-sucker) sebagai batang bawah dan cabang yang akan digunakan sebagai batang atas. Syarat untuk batang bawah (root stock) dan (batang atas) scion yang digunakan adalah ukuran diameter rootstock dan scion mesti sama. Batang atas berasal dari tanaman yang sudah berbunga. Selain itu juga diterangkan tujuan dari setiap tahapan grafting mulai dari pemotongan anakan dan cabang untuk batang atas, pengikatan, penutupan dengan plastik, pemeliharaan hingga peletakan hasil sambungan di bawah naungan paranet.

Pelatihan dilakukan terhadap anggota kelompok tani menggunakan batang bawah yang berasal dari anakan yang telah mereka persiapkan pada kegiatan sebelumnya. Sebelum pelatihan dibagikan pisau/ gunting setek. Umumnya anggota kelompok tani bersemangat dan bersungguh-sungguh dalam melakukan grafting (Gambar 4). Setelah selesai, dilakukan penilaian terhadap hasil grafting dan diskusi mengenai beberapa kesalahan pada saat melakukan grafting. Pada akhir kegiatan dibagikan bibit hasil sambung dari kegiatan tahun 2015 dan juga bibit grafting hasil pelatihan (Gambar 5). Keberhasilan grafting ditandai dari munculnya tunas atau daun yang berasal dari cabang yang digunakan sebagai batang atas.

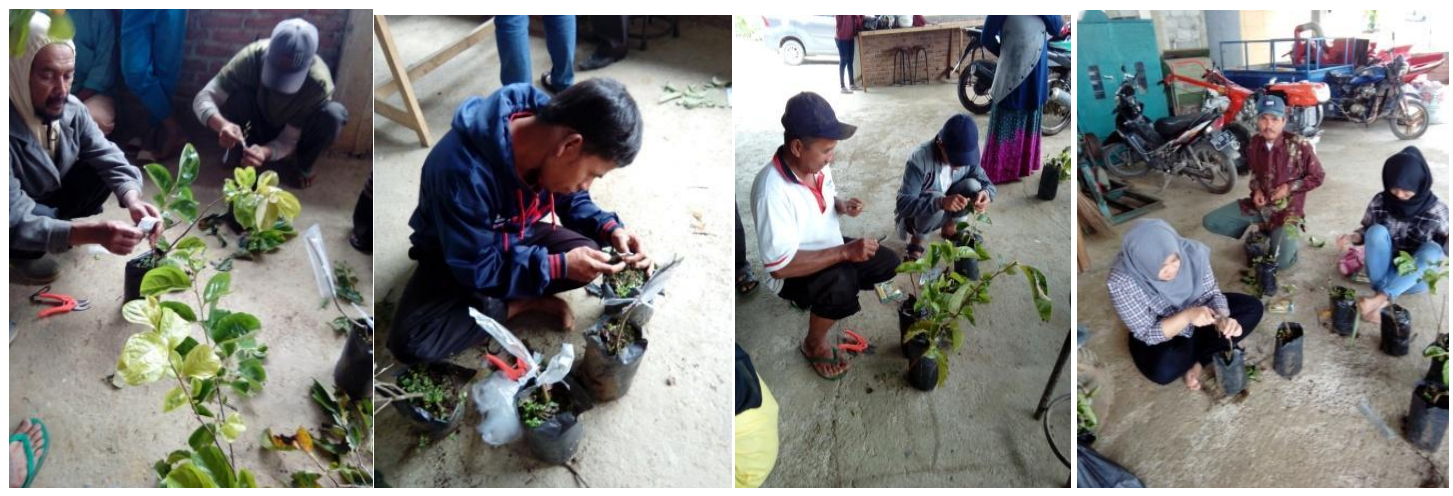

Gambar 4. Pelatihan Sambung (Grafting) Tanaman Kesemek 

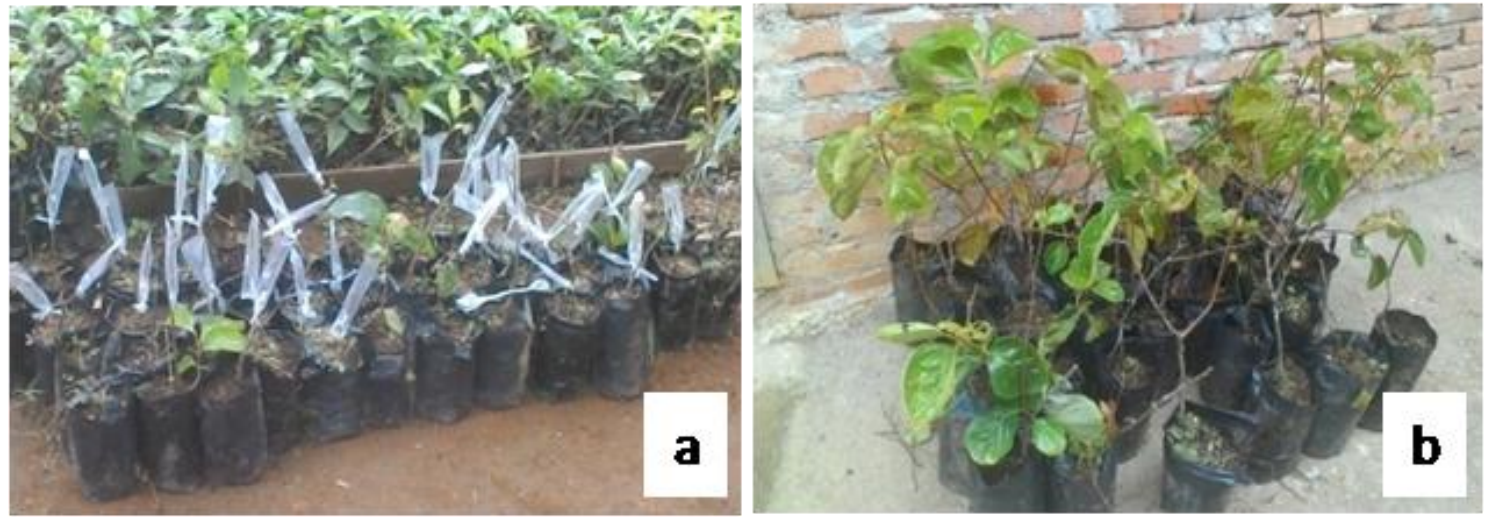

Gambar 5. Bibit Hasil Sambung Pucuk Pada Tanaman Kesemek; (a) Grafting Yang Dilakukan Oleh Petani dan (b) Sebagian Bibit Hasil Grafting Yang Dibagikan Kepada Petani.

Evaluasi yang dilakukan terhadap 30 orang petani mitra menggunakan analisis Likert menunjukkan bahwa kegiatan yang dilakukan berhasil mentransfer pengetahuan maupun keterampilan mengenai grafting kepada petani dengan indeks keberhasilan sebesar 0.92. Analisis Likert menunjukkan besaran nilai indeks atau persentase untuk mengukur sikap dan persepsi seseorang ataupun fenomena sosial (Suryabrata, 2012). Nilai indeks atau persentase diperoleh dari besaran rasio jumlah skor responden dengan skor ideal (tertinggi) (Rusydi et al, 2015).

Sebanyak $88 \%$ petani menganggap kegiatan memiliki kesesuaian dengan kebutuhan/permasalahan yang ada. Seluruh peserta menganggap kontribusi terbesar dari tim Universitas Andalas adalah pengetahuan dan keterampilan. Baik penyuluhan, demonstrasi dan pelatihan bermanfaat bagi seluruh peserta, demikian juga dengan pemberian peralatan dan tanaman hasil grafting yang dibagikan. Evaluasi terhadap waktu pelaksanaan menunjukkan bahwa waktu penyuluhan dan pelatihan perlu ditambah sehingga kegiatan ini perlu dilanjutkan.

\section{KESIMPULAN DAN SARAN}

Luaran dari kegiatan adalah petani meningkat pengetahuannya mengenai manfaat buah kesemek, teknik budidaya dan pasca panen kesemek. Petani mampu menerapkan teknologi perbanyakan dengan teknik grafting atau sambung menggunakan anakan rootsucker sebagai batang bawah untuk perbanyakan tanaman kesemek. Hasil analisis Likert menunjukkan nilai capaian 92\%, mengindikasikan bahwa kegiatan yang dilakukan bermanfaat atau berhasil mentransfer pengetahuan dan juga keterampilan kepada petani. Kegiatan transfer teknologi grafting ini belum menjangkau seluruh masyarakat di Alahan Panjang sehingga kegiatan serupa dengan skala kegiatan yang lebih besar perlu dilakukan untuk mempertahankan keberadaan dan memasyarakatkan tanaman kesemek di Alahan Panjang. 


\section{UCAPAN TERIMA KASIH}

Penulis mengucapkan terima kasih kepada LPPM Universitas Andalas atas hibah pengabdian kompetitif DIPA Universitas Andalas No: 644/XIII/A/Unand/2016 tanggal 22 April 2016. Ucapan terima kasih yang sama juga disampaikan kepada bapak Triono dari PATPKP Unand yang telah membantu kegiatan penelitian kesemek dari tahun 2014 - 2015, serta bapak Bambang Kuswara, SP dari Balitbu Tropika Solok atas bantuan teknis penyambungan kesemek yang dilakukan tahun 2015.

\section{DAFTAR PUSTAKA}

Chen, XN., J.F. Fan, X. Yue, XR. Wu, and L.T. Li. 2008. Radical scavenging activity and phenolic compounds in persimmon (Diospyros kaki L. cv.Mopan). Journal of Food Science. 7(3): 24-28.

Dewi-Hayati, P.K. 2014. Kesemek: Pengenalan, Pengolahan Buah dan Propagasi Tanaman. Modul 07. PATPKP. Universitas Andalas.

Dewi-Hayati, P.K., I. Darfis dan A. Anwar. 2014. Propagasi Tanaman Kesemek (Diospyros kaki Thunb.) di Kabupaten Solok. Laporan Akhir Kegiatan PATPKP. Universitas Andalas.

Efrizal., Rusnam dan F. L. Syaiful. 2018. Diseminasi teknologi pembuatan pakan buatan alternatif dengan campuran limbah kangkung air, Ipomoea aquatica Forks untuk pembudidaya ikan di Sumatera Barat. Jurnal Hilirisasi IPTEKS. 1(3): 1-10.

Jung, S., Y. Park, Z. Zachwieja, M. Folta, H. Barton, and J. Piotrowicz. 2005. Some essential phytochemicals and the antioxidant potential in fresh and dried persimmon. Inter. J. of Food Sci. and Nutr. 56(2): 105-113.

Nazir, A., S.M. Wani, A. Gani, F.A. Masoodi, E. Haq, S.A. Mir, and U. Riyaz. 2013. Nutritional, antioxidant and antiproliferative properties of persimmon (Diospyros kaki) a minor fruit of $\mathrm{J} \& \mathrm{~K}$ India. Inter. J. of Adv. Res. 1(7):545-554

Rusydi, I., S. Siswanti, dan W. Laksito YS. (2015). Analisis efektivitas pemanfaatan multimedia pada pencitraan AMIK Amikom Cipta Darma Surakarta. J. Teknologi Informasi dan Komunikasi (TIKomSiN) 3(2):34-41

Suryabrata, S. 2012. Metodologi Penelitian. Rajawali Pers, Yogyakarta

Syaiful, F.L. 2018. Desiminasi teknologi deteksi kebuntingan dini "Deea Gestdect" terhadap sapi potong di Kinali Kabupaten Pasaman Barat. Jurnal Hilirisasi IPTEKS. 1(3): 18-25.

Tetsumura, T., R. Tao, and A. Sugiura. 2000. Single-node stem cuttings from root suckers to propagate a potentially dwarfing rootstock for Japanese persimmon. Hort. Tech. 10(4):776-780. 